\title{
Surgical Position, Cause of Extracranial Internal Carotid Artery Dissection, Presenting as Pourfour Du Petit Syndrome: Case Report and Literature Review
}

\author{
Cerrabi Pozisyon Nedeniyle Ekstrakraniyal Internal Karotid Arter \\ Diseksiyonunun Pourfour Du Petit Sendromu Olarak Ortaya Çıkması: \\ Olgu Sunumu ve Literatür Derlemesi
}

Gloria VILLALBA MARTINEZ ${ }^{1}$, Irene NAVALPOTRO GOMEZ ${ }^{2}$, Laura SERRANO PEREZ ${ }^{1}$, Sofia GONZALEZ ORTIZ ${ }^{3}$, Juan L FERNÁNDEZ-CANDIL ${ }^{4}$, Eva Giralt STEINHAUER ${ }^{2}$

${ }^{1}$ Hospital del Mar, Neurosurgery Department, Barcelona, Spain

${ }^{2}$ Hospital del Mar, Neurology Department, Barcelona, Spain

${ }^{3}$ Hospital del Mar, Neuroradiology Department, Barcelona, Spain

${ }_{4}^{4}$ Hospital del Mar, Anesthesiology Department, Barcelona, Spain

Corresponding Author: Gloria Villalba MARTíNEZ / E-mail: gloriavillalbamartinez@gmail.com

\begin{abstract}
Dissection of the internal carotid artery is a rare cause of stroke overall, but causes $22 \%$ of strokes in younger patients. A common clinical presentation is as Claude Bernard Horner syndrome. We report a craniotomy with 30 degrees rotation of the neck (standard position) in a patient with no major risk factors for carotid dissection, who showed a Pourfour du Petit syndrome due to a dissection of the internal carotid artery. To the best of our knowledge, this is the first reported case in which a common surgical position causes an internal carotid artery dissection in a patient without relevant risk factors. The presentation with Pourfour du Petit syndrome is extremely unusual.
\end{abstract}

KEYWORDS: Carotid dissection, Pourfour du Petit syndrome, Neck rotation

öz

Internal karotid arter diseksiyonu genel olarak inmenin nadir bir nedenidir ama daha genç hastalarda inmelerin \%22'sine neden olur. Sık görülen bir klinik sunum Claude Bernard Horner sendromudur. Karotid diseksiyon için majör risk faktörleri olmayan ve boynun 30 derece rotasyonuyla (standart pozisyon) kraniyotomi yapılan bir hastada internal karotid arter diseksiyonu nedeniyle Pourfour du Petit sendromu gelişmesini sunuyoruz. Bildiğimiz kadarıyla bu ilgili risk faktörleri olmayan bir hastada sık kullanılan bir cerrahi pozisyonun internal karotid arter diseksiyonuna neden olduğu ilk bildirilen olgudur. Pourfour du Petit sendromu ile birlikte durum son derece nadirdir.

ANAHTAR SÖZCÜKLER: Karotid diseksiyonu, Pourfour du Petit sendromu, Boyun rotasyonu

\section{INTRODUCTION}

Carotid artery dissection is a rare cause of stroke. Although responsible for only about $2.5 \%$ of all strokes, it accounts for up to $22 \%$ of strokes in younger patients. The most common age group is between 35 and 50 years old, with a distinct peak incidence in the fifth decade; the prevalence is similar in both sexes. Extracranial internal carotid artery (ICA), from the carotid bulb to the cranial base, is more vulnerable to dissection compared to the intracranial portion; the most frequent dissection is $2-3 \mathrm{~cm}$ distal to the carotid bulb. The dissection can be classified as spontaneous or traumatic. Intrinsic factors associated with or predisposing to spontaneous dissection include the following: aortic root dilation, bicuspid aortic valve, increased arterial compliance and arterial wall stiffness, elevated CRP levels, fibromuscular dysplasia, genetic factors, hypertension, hypercholesterolemia; and connective tissue diseases (e.g., Ehler-Darlos syndrome type IV, Marfan syndrome, autosomal dominant polycystic kidney disease, osteogenesis imperfecta, alpha 1 antitrypsin deficit) $(1,5,14$, 25).

Traumatic dissection can occur by direct blow to the neck or by hyperextension, rotation or lateroversion of the neck. Sometimes the trauma is so mild that it is misclassified as spontaneous dissection. Minor traumas reported in literature 
include vomiting, painting a ceiling, a long telephone conversation, riding a roller coaster, and practicing yoga. Among the iatrogenic causes reported in literature are neck manipulations in anesthetized patients, aspiration with fine needles, and postcardiac resuscitation. Infection, particularly in the respiratory system, has been implicated as a trigger for carotid artery dissection $(2,6,7,10-13,15,17,18,23)$.

A large percentage of patients with carotid artery dissection are asymptomatic. In symptomatic patients, the clinical manifestations may be due to local complications. Facial or neck pain is the most common symptom and usually the first to appear, partial Claude Bernard Horner syndrome (CBHS) occurs in $50 \%$ of patients. Other symptoms include headache, unilateral or pulsatile tinnitus, amaurosis fugax, retinal infarct, and palsies of the lower cranial nerves (the hypoglossal being the most frequently affected). On the other hand, signs of ischemia may be present in $50 \%$ to $90 \%$ of cases. Most strokes occur in the first week of local symptoms onset and are located in the territory of the middle cerebral artery. Diagnosis can be made by angiography, computed tomography angiography (CTA), magnetic resonance angiography (MRA) and ultrasound (20). Differential diagnosis is required with respect to cluster headache, migraine, retinal artery occlusion, herpes zoster and musculoskeletal neck pain $(16,19,24)$.

There is currently no consensus on the treatment of carotid artery dissection. In patients with an acute neurological deficit, intravenous thrombolysis or even endovascular treatment may be a possibility. In general, anticoagulation with heparin has been the treatment in the acute phase and subsequently acenocoumarol. More recently, and especially in asymptomatic patients, antiplatelet therapy has become the most commonly used treatment $(4,8,13,19,22,26)$.

\section{CASE REPORT}

In March 2012, a 43-year old woman with insulindependent diabetes mellitus and hypercholesterolemia had a subarachnoid hemorrhage due to the rupture of a left terminal carotid aneurysm. The aneurysm was embolized. As complications of subarachnoid haemorrhage, severe vasospasm of right middle cerebral artery (MCA) and right anterior cerebral artery (ACA) occurred, leading to a right frontal cerebral infarct and hydrocephalus that required ventriculoperitoneal shunt.

The first arteriography showed the existence of an unruptured polylobulated aneurysm of the right MCA. Three months later, a new arteriography showed a left terminal carotid embolized aneurysm that was totally excluded, and a right middle cerebral artery aneurysm, proposed for open surgery. No carotid artery dissection or other problems were observed. In November 2012, a preoperative MRA was performed; no change was observed. In January 2013, the patient had a seizure, and a CTA was performed. It showed no changes from previous images and normal ICA diameters (Figure 1).

Surgery was performed in March 2013 under general anesthesia and neurophysiological monitoring, with the patient in supine position, head slightly hyperextended and lateralized to the left 30 degrees. We performed a right frontotemporal craniotomy, dissected the Sylvian valley and exposed the aneurysm. The right middle cerebral artery was temporarily clipped for 18 minutes and then definitively, with two clips. The surgery lasted 5 hours. No anesthesiological or neurophysiological problems were detected (Figure 2).

The patient had a delay in awakening (30 minutes), and showed left anisocoria, (which reversed in about 24 hours). Postoperative CT showed no complications.

Postoperative arteriography was performed 48 hours after surgery, showing complete occlusion of the left ICA in its extracranial portion and leading to the diagnosis of carotid dissection. The clipped aneurysm was excluded from circulation (Figure 3)

Antiplatelet therapy with acetylsalicylic acid $100 \mathrm{mg}$ was started. Cranial MRI did not show any acute ischemic lesions.

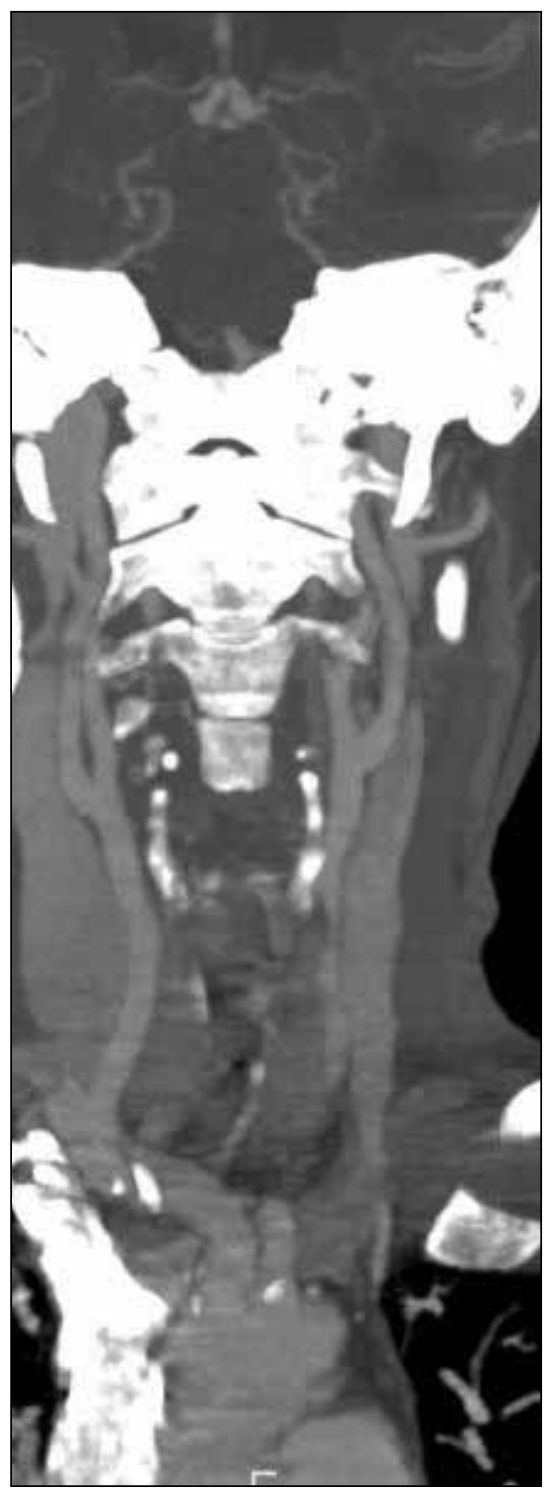

Figure 1: Cerebral tomography angiography of the supraaortic trunks. The internal carotid arteries are permeable, with normal diameters. 


\section{DISCUSSION}

This is the first case reported in the literature of carotid dissection due to a common surgical position. The patient had no relevant risk factors, such as fibromuscular dysplasia, that predispose to carotid dissection. The 30 degrees rotation of the head used in this case is the standard access to MCA aneurysms. There is a clear temporal association between the anisocoria and the surgery. Therefore, we can say that carotid

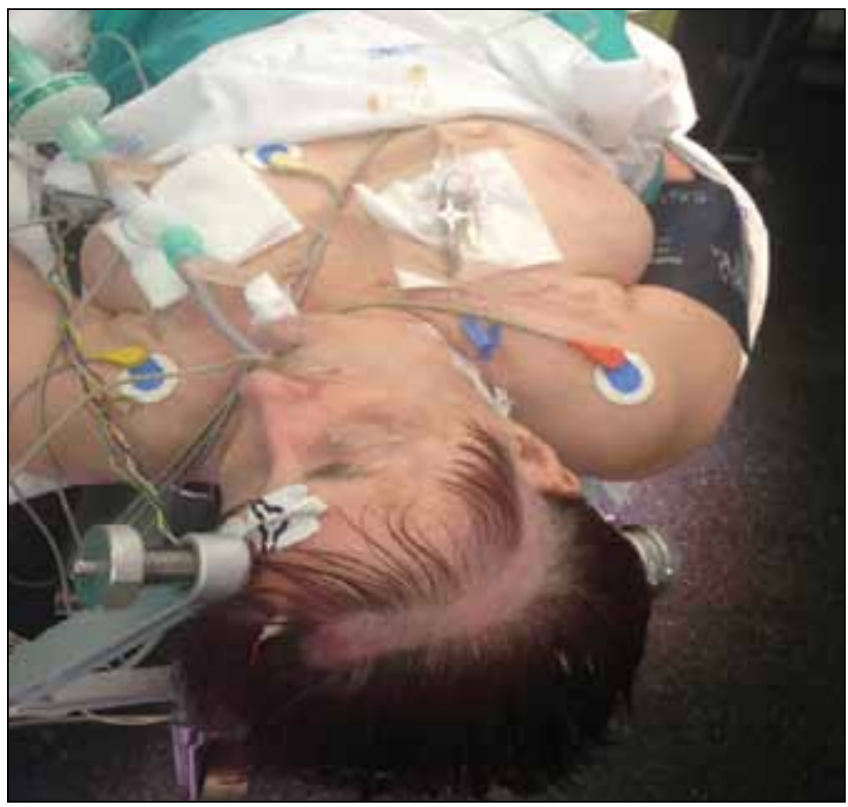

Figure 2: Head position during the 5-hour surgery. The head is rotated 30 degrees to the left.

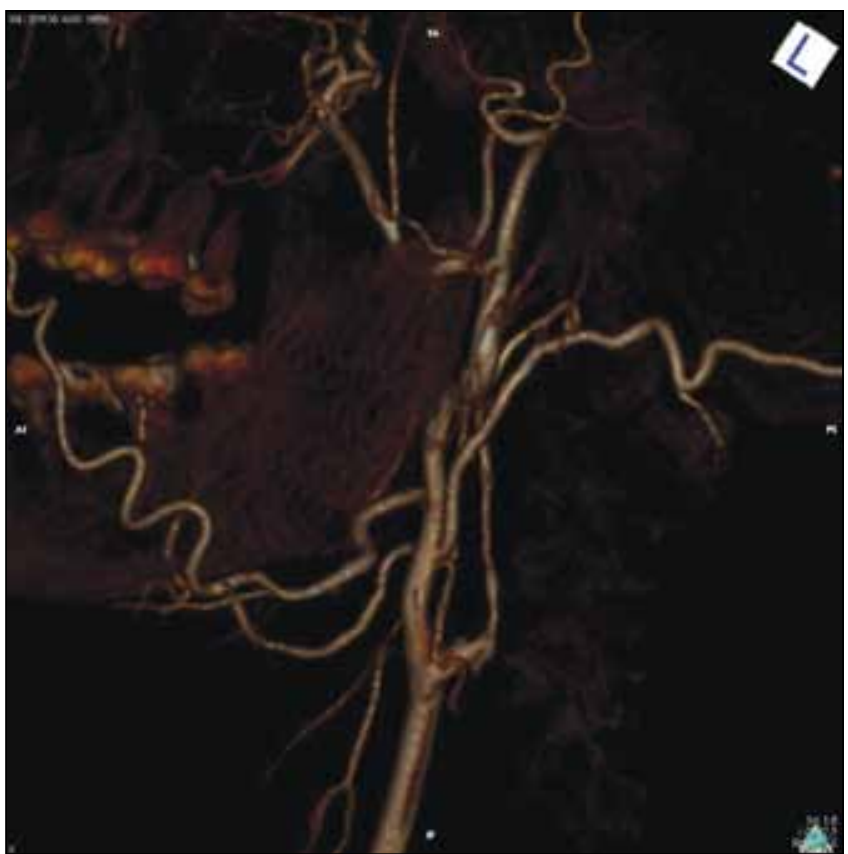

Figure 3: Postoperative cerebral arteriography reconstruction showing complete occlusion of the left internal carotid artery in its extracranial portion. dissection was not spontaneous. It likely resulted from the 5 hours of neck rotation.

The literature describes cases of dissection due to forced positions of the neck, especially in patients with risk factors $(9,11-13,21)$, but there are no case reports for a common surgical position.

In this case, carotid dissection was asymptomatic from the ischemic cerebral standpoint, probably due to compensation from the right hemisphere. Interestingly, the 18-minute temporary clipping of the MCA during the surgical procedure did not interfere with that compensation. Anesthetic monitoring revealed no changes during surgery. Intraoperative neurophysiological monitoring was performed including an electroencephalogram, somatosensory evoked and motor evoked potentials after stimulating the median and tibial nerve. The recordings were stable throughout surgery. We wonder whether such compensation would have been possible if the temporary clipping had been maintained longer.

The clinical presentation of carotid dissection with mydriasis is unusual. If there is pupillary involvement, it is more common in the context of CBHS due to injury of the sympathetic nerve fibers, with its classic triad of miosis, enophthalmos and ptosis $(16,19,22,24)$. Pourfour du Petit syndrome (PDPS), a little known entity and the inverse of $\mathrm{CBHS}$, is characterized in its complete form by mydriasis, exophthalmos, upper eyelid retraction with increased lid fissure and periorbital hyperhidrosis. All of these are evidence of irritation (hyperexcitation) of the ipsilateral cervical sympathetic nerve chain. Other causes of PDPS described in the literature include cervicofacial trauma, thyroid tumors, primitive carotid aneurysms, and iatrogenic causes. Recognition of this syndrome is valuable for its high locator value, making possible the early diagnosis of various potentially serious pathologies (3).

Therapeutic management of these patients varies from antithrombotic drugs to complex endovascular and surgical techniques in the series and observational studies reported in the literature $(6,19,26)$. Choosing the best drug treatment remains controversial. In the absence of randomized studies, the superiority of anticoagulant therapy compared to antiplatelet therapy has not yet been demonstrated. Antiplatelet therapy was chosen in our patient, after assessing both treatments for effectiveness and safety (given her history of recent surgery).

\section{CONCLUSION}

Standard surgical position in neurosurgery that involves prolonged neck rotation may cause carotid dissection. Therefore, postoperative neurological examination, especially if the signs and symptoms have no correlation with the surgical site, must always take into account this possible diagnosis, especially in patients with risk factors (e.g., fibromuscular dysplasia).

Pupillary dilation must be considered as a clinical manifestation of ICA dissection in the context of PDPS. 


\section{REFERENCES}

1. Ahmad HA, Gerraty RP, Davis SM, Cameron PA: Cervicocerebral artery dissections. Jaccid Emerg Me 16:422-424, 1999

2. Assendelft WJ, Bouter LM, Knipschild PG: Complications of spinal manipulation. A comprehensive review of the literature. J Family Pract 42:475-480, 1996

3. Balik V, Kolembus P, Svajdler M, Sulla I, Vaverka M, Hrabalek $\mathrm{L}$ : A case report of rapid spontaneous redistribution of acute supratentorial subdural hematoma to the entire spinal subdural space presenting as a Pourfour du Peit syndrome and review of the literature. Clin Neurol Neurosurg 115(7):849852,2012

4. CADISS Trial Investigators: Antiplatelet therapy versus anticoagulation in cervical artery dissection: Rationale and design of the cervical artery dissection in stroke study (CADISS). International Journal of Stroke 2:292-296, 2007

5. Debette S, Leys D: Cervical artery dissections: Predisposing factors, diagnosis and outcome. Lancet Neurol 8:668-678, 2009

6. Dziewas $R$, Konrad C, Drager B, Evers $S$, Besselman $M$, Kuhlenbaumer G, Stogbauer F, Ringelstein EB: Cervical artery dissection-clinical features, risk factors, therapy and outcome in 126 patients. J Neurol 250:1179-1184, 2003

7. Ernst E: Vascular accidents after neck manipulation. Cause or coincidence? Int J Clin Practice 64:673-677, 2010

8. Georgiadis D1, Lanczik O, Schwab S, Engelter S, Sztajzel R, Arnold M, Siebler M, Schwarz S, Lyrer P, Baumgartner RW: IV thrombolysis in patients with acute stroke due to spontaneous carotid dissection. Neurology 64:1612-1614, 2005

9. Gould DB, Cunninham K: Internal carotid artery dissection after remote surgery. latrogenic complications of anesthesia. Stroke 25:1276-1278, 1994

10. Haneline MT, Lewkovich GN: An analysis of the etiology of cervical artery dissection:1994 to 2003. J Manipulative Physiol Ther 28: 617-622, 2005

11. Haynes MJ, Vincent K, FischhoffC, Bremner AP, Lanlo O, Hankey GJ: Assessing the risk of stroke from neck manipulation a systematic review. Int J Clin Pract 66(10):940-947, 2012

12. Kapral MK, Bondy SJ: Cervical manipulation and the risk of stroke. CMAJ 165:907-908, 2001

13. Koennecke $\mathrm{H}$, Friedwald JP, Hartigan M: latrogenic dissection of the common carotid artery: Diagnosis by dynamic image and color flow Doppler ultrasonography. J Clin Ultrasound 19:250-253, 1991

14. Lee VH, Brown RD, Jayawant N, Mandrekar JN, Mokri B: Incidence and outcome of cervical artery dissection. A population based study. Neurology 67:1809-1812, 2006
15. Lleva P, Ahluwalia BS, Marks S, Sahni R, Tenner M, Risucci DA, Lai HM, Li J:Traumatic and spontaneous carotid and vertebral artery dissection in a level 1 trauma center. Journal of Clinical Neuroscience 19:1112-1114, 2012

16. Mokri B, Sundt TM, Houser OW: Spontaneous internal carotid dissection, hemicrania, and Horner's syndrome. Arch Neurol 36:677-680, 1979

17. Nassenstein I, Bachmann R, Ringelstein EB, Kuhlenbaumer $G$, Nabavi DG: Mild mechanical traumas are possible risk factors for cervical artery dissection. Cerebrovasc Dis 23:275-281, 2007

18. Norris JW, Beletsky V, Nadareishvili Z: Sudden neck movement and cervical artery dissection. Can Med Assoc J 163:38-40, 2000

19. Patel R, Adam R, Madljian C, Lincoln C, Yuen A, Arneja A: Cervical Carotid artery dissection: Current review of diagnosis and treatment. Cardiology in Review 20(3):145-150, 2012

20. Rodallec MH, MArteau V, Gerber S, Desmottes L, Zins M: Craniocervical arterial dissection: Spectrum of imaging findings and differential diagnosis. Radiographics 28:17111728, 2008

21. Rubinstein S, Peerdeman S, Van Tulder M, Riphagen I, Haldeman S: A systematic review of the risk factors for cervical artery dissection. Stroke 36:1575-1580, 2005

22. Schwartz NE, Vertinsky AT, Hirsch KG: Clinical and radiographic natural history of cervical artery dissections. J Stroke Cerebrovasc Dis 18:416-423, 2009

23. Shelfaut D, Dhondt E, De Raedt S, Nieboer K, Hubloue I: Carotid artery dissection: Three cases and a review of the literature. European Journal of Emergency Medicine 19: 181-187, 2012

24. Thomas L, Rivett D, Attia J, Levi C: Risk factors and clinical presentation of craniocervical arterial dissection: $A$ prospective study. BMC Musculoskeletal Disorders 13:164169,2012

25. Zach V, Shovtis S, Kirchoff-Torres K, Weinberger JM: Common carotid artery disecction: A case report and review of the literature. Journal of Stroke and Cerebrovascular Diseases 21(1): 52-60, 2012

26. Zinkstok $S$, Vergouwen $M$, Engelter $S$, Lyer $P$, Bonati $L$, Arnold $M$, Mattle $\mathrm{H}$, Fiscer $\mathrm{U}$, Sarikaya $\mathrm{H}$, Baumgartner R, Georgiadis D, Odier C, Michel P, Putaala J, Griebe M, Wahlgren N, Ahmed N, Geloven N, Hann R, Nederkoorn P: Safety and functional outcome of thrombolysis in dissection related ischemic stroke: A meta-analysis of individual patient data. Stroke 42(9):2515-2520,2011 